\title{
Changes of Progesterone and Endothelin Concentrations in the Peripheral Plasma of Female Calves and Cycling Cows: Effects of $\mathrm{PGF}_{2 \alpha}$ Injection
}

\author{
Masayuki OHTANI ${ }^{1)}$, Naoko OKI ${ }^{2)}$, Miyune TANIMURA ${ }^{2)}$, Shu-ichi KOBAYASHI ${ }^{2)}$, \\ Tomas J. ACOSTA2), Kanako HAYASHI ${ }^{2)}$ and Akio MIYAMOTO2) \\ 1) The University Farm, and ${ }^{2)}$ Department of Animal Science, Obihiro University of Agriculture \\ and Veterinary Medicine, Obihiro 080-8555, Japan
}

\begin{abstract}
It is well known that an injection of prostaglandin $\mathrm{F}_{2 \alpha}\left(\mathrm{PGF}_{2 \alpha}\right)$ or its analogue during the mid luteal phase of the estrous cycle induces a rapid decrease in plasma progesterone $\left(\mathrm{P}_{4}\right)$ concentration, followed by luteolysis in the cow. There is evidence that a potent vasoactive peptide, endothelin-1 (ET-1), is produced in the bovine corpus luteum (CL), and that it is directly involved in luteolysis. We previously found that ET-1 concentrations in the peripheral plasma increase during the period of luteolysis and ovulation in cows. However, it is not clear whether the elevation of peripheral plasma ET-1 concentration observed during luteolysis and ovulation originates exclusively from the ovary and/or CL. Such a profile of plasma ET-1 concentration may be affected by the age of female calves as well as the activity of the ovary. Thus, we aimed to 1) determine in detail the changes in plasma ET-1 and $\mathrm{P}_{4}$ concentrations during the estrous cycle in the cow, 2) investigate plasma changes in ET- 1 and $\mathrm{P}_{4}$ concentrations in new-born, 120-day-old and 240-day-old female calves, and 3) examine the effect of luteolytic injection of $\mathrm{PGF}_{2 \alpha}$ analogue on the plasma ET-1 concentrations in the animals in this study. The peripheral plasma ET-1 concentrations in the cycling cows showed a pulsatile increase. They reached the their highest level $(13.66 \mathrm{pg} / \mathrm{ml})$ around the time of luteolysis and estrus, dropped significantly during Days 2-12 (early to mid luteal phase) and Days 13-19 (late luteal phase) $(\mathrm{p}<0.05)$, and then increased again on Days 20-22 $(\mathrm{p}<0.05)$ when the next estrus appeared. In the peripheral plasma of newborn, 120-day- old and 240-day-old female calves, $\mathrm{P}_{4}$ concentrations remained at low levels $(0.1-0.2 \mathrm{ng} / \mathrm{ml})$. ET-1 concentrations in these animals were lower than those in the cycling cows, and remained at low levels throughout the experimental period. Moreover, plasma ET-1 concentrations, unlike those in the cycling cow, did not change after a luteolytic PGF $_{2 \alpha}$ injection. In conclusion, the results of the present study gave the first detailed information that plasma ET-1 concentrations increase in a pulsatile manner after the onsets of spontaneous luteolysis and $\mathrm{PGF}_{2 \alpha^{-}}$ induced luteolysis in cycling cows, but not in female calves. The results suggest that the changes in the plasma ET-1 concentrations during the estrous cycle directly correlate with the cyclic changes in the ovarian function and the uterus.
\end{abstract}

Key words: Endothelin, Progesterone, Plasma, Calves, Cows.

(J. Reprod. Dev. 47: 37-43, 2001)

$t$ is well known that an injection of prostaglandin $\mathrm{F}_{2 \alpha}\left(\mathrm{PGF}_{2 \alpha}\right)$ or its analogue

Accepted for publication: November 29, 2000

Correspondence: A. Miyamoto during the mid luteal phase of the estrous cycle induces a rapid decrease in plasma progesterone $\left(\mathrm{P}_{4}\right)$ concentration, followed by luteolysis in the cow. There is evidence that the blood flow in the ovarian artery ipsilateral to the regressing corpus 
luteum (CL) also decreases dramatically at this stage $[1,2]$.

Endothelin-1 (ET-1), a potent vasoactive peptide consisting of 21 amino acids, was originally isolated from cultured endothelial cells [3]. It is also produced in the bovine $C L$, and its production increases 3-fold after the onset of luteolysis in comparison with that in the early to mid luteal phase [4]. In addition, the expression of the endothelin type $A$ receptor $\left(E T_{A}-R\right)$ mRNA in bovine CL increases about 2.5-fold at luteolysis [5]. Furthermore, ET-1 has been shown to suppress $\mathrm{P}_{4}$ production in bovine luteal cell culture [6]. We have also shown that an infusion of ET-1 into an in vitro microdialysis system (MDS) implanted within the midcycle bovine CL suppresses $\mathrm{P}_{4}$ release, and that this inhibiting effect was apparently potentiated by preperfusion with $\mathrm{PGF}_{2 \alpha}[7,8]$. We have further found that by using in vivo MDS surgically implanted into the midcycle CL, the ET-1 secretion after a luteolytic injection of $\mathrm{PGF}_{2 \alpha}$ rapidly increased within the regressing CL. This increase was accompanied by an increase in ET-1 concentrations in the ovarian venous plasma (OVP) ipsilateral to the $\mathrm{CL}$ and also in the jugular venous plasma (JVP) [9]. All of the above findings strongly suggest that ET-1 secretion in the CL correlates directly to luteolysis in the cow, which involves both $\mathrm{P}_{4}$ suppression and vasoconstriction.

Vascular endothelial cells are not only the structure of the blood container, but also they have the ability to produce and release ET-1 [10]. These cells are distributed in the whole body, and locally secreted ET-1 has numerous functions [11, 12]. Therefore, it was not clear whether the elevation of peripheral plasma ET-1 concentration observed during luteolysis and ovulation originates exclusively from the ovary and/or CL. Such a profile of plasma ET-1 concentration may be affected by the age of female calves as well as the activity of the ovary.

In this study, we aimed to 1) determine in detail the changes in plasma ET- 1 and $\mathrm{P}_{4}$ concentrations during the estrous cycle in the cow; 2) investigate plasma changes in ET-1 and $\mathrm{P}_{4}$ concentrations in new-born, 120-day-old and 240-day-old female calves; and 3) examine the effect of luteolytic injection of a $\mathrm{PGF}_{2 \alpha}$ analogue on the plasma ET-1 concentrations in these animals. The obtained data indicated that the ovarian cycle, particularly luteolysis and estrus, was directly correlated with the increase in peripheral plasma ET-1 concentration. In contrast, the calves without an ovarian cycle showed no change in plasma ET-1 concentration.

\section{Materials and Methods}

\section{Experimental design and animals}

The first study was designed to determine $\mathrm{P}_{4}$ and ET-1 concentrations in the peripheral plasma during the estrous cycle. Five multiparous lactating Holstein cows in the mid luteal phase were used for this purpose. They had at least 2 estrous cycles of normal length (21-22 days) before being used. Twelve hours after the first blood samples were collected, five hundred micrograms of the $\mathrm{PGF}_{2 \alpha}$ analogue cloprostenol (Estrumate, Sumitomo Pharm. Co., Osaka, Japan) was injected intramuscularly on Days 10-12 to induce luteolysis. Three days after the $\mathrm{PGF}_{2 \alpha}$ injection, all five cows showed estrus. This was designated as Day 0. Blood samples were collected for the next 21-23 days until the following estrus and ovulation were confirmed. A 16-gauge catheter (Medicut Catheter Kit; Argyle Co., Japan Sherwood, Tokyo, Japan) was inserted into the jugular vein and sutured. Blood samples $(10 \mathrm{ml})$ were collected from this catheter at 3-h intervals during Days -3.5 to 3, Days 8 to 11 and Days 17 to 23 , and at 12-h intervals during other periods.

The second study used three groups of six calves, with ages of 1 day, 120 days, and 240 days. The start of the experiment was designated as Day 1. Blood samples $(10 \mathrm{ml})$ were collected once a day $(0600 \mathrm{~h})$ from Day 1 to Day 20, and at 12-h intervals (0600 and $1800 \mathrm{~h}$ ) from Day 21 to Day 26 from the jugular vein with disposable syringes. Five hundred micrograms of $\mathrm{PGF}_{2 \alpha}$ analogue was intramuscularly injected at Day 22 immediately after the morning blood sampling.

The blood samples were collected in sterile glass tubes containing $200 \mu \mathrm{l}$ of a stabilizer solution ( 0.3 M EDTA, 1\% acid acetyl salicylic, pH 7.4) and were immediately chilled in ice water for $10 \mathrm{~min}$ and then centrifuged at $900 \times \mathrm{g}$ for $20 \mathrm{~min}$ at $4 \mathrm{C}$. The obtained plasma was stored at $-30 \mathrm{C}$ until further analysis.

Extraction for plasma $P_{4}$

The plasma samples $(200 \mu 1)$ for the $\mathrm{P}_{4}$ 
determinations were extracted by diethyl ether as described previously [9]. The residue was dissolved in $200 \mu \mathrm{l}$ of assay buffer (40 mM PBS, $0.1 \%$ BSA, pH 7.2). The recovery rate of plasma $\mathrm{P}_{4}$ was previously found to be $85 \%$ in our laboratory.

\section{Extraction of plasma ET-1}

The plasma samples $(3 \mathrm{ml})$ were diluted with 3 $\mathrm{ml}$ of distilled water, and the $\mathrm{pH}$ was adjusted to 2.5 with $5 \mathrm{~N} \mathrm{HCl}$. The samples were then applied to a Sep-Pak C18 Cartridge (Waters, Millford, MA) as described previously [7]. The residue was evaporated and then dissolved in $200 \mu \mathrm{l}$ of assay buffer $\left(42 \mathrm{mM} \mathrm{Na} 2 \mathrm{HPO}_{4}, 8 \mathrm{mM} \mathrm{KH} \mathrm{PO}_{4}, 20 \mathrm{mM}\right.$ $\mathrm{NaCl}, 4.8 \mathrm{mM}$ EDTA, $0.05 \% \mathrm{BSA}, \mathrm{pH} 7.5)$ for the ET-1 enzyme immunoassay (EIA). The plasma samples were concentrated 15 -fold as a result of this process and this enabled us to determine ET-1 concentration in the EIA within the range of the standard curve. The recovery rate of plasma ET-1 $(50 \mathrm{pg} / \mathrm{ml})$ that had been added to the plasma was $53 \%$. All values of ET-1 concentration in the present study were corrected by the recovery rate.

\section{Hormone determination}

$\mathrm{P}_{4}$ and ET- 1 concentrations were determined in the plasma with second-antibody EIAs that were based on a competitive assay using horseradish peroxidase-labeled $\mathrm{P}_{4}$ or biotin-labeled ET-1 as tracers.

Concentrations of $\mathrm{P}_{4}$ were assayed as described in detail previously [13]. The standard curve of $\mathrm{P}_{4}$ ranged from 0.05 to $50 \mathrm{ng} / \mathrm{ml}$, and the $\mathrm{ED}_{50}$ of the assay was $1.8 \mathrm{ng} / \mathrm{ml}$. The intra- and interassay coefficients of variation ( $\mathrm{CVs}$ ) were on average $6.2 \%$ and $9.3 \%$, respectively. The EIA for ET- 1 was conducted as described previously [7]. The standard curve of ET-1 ranged from 9.7 to $5000 \mathrm{pg} /$ $\mathrm{ml}$, and the $\mathrm{ED}_{50}$ of the assay was $450 \mathrm{pg} / \mathrm{ml}$. The intra- and interassay CVs of the ET-1 assay were on average $8.7 \%$ and $12.6 \%$, respectively.

\section{Statistical analysis}

In order to analyze the changes in the plasma concentrations of $\mathrm{P}_{4}$ and ET- 1 , the estrous cycle was divided into four periods (Days -2 to 1 , Days 2 to 12, Days 13 to 19 and Days 20 to 22). The absolute concentrations of each hormone during these periods were averaged, and the mean values were compared with each other. The mean values were calculated using all the data from within the respective periods. Means were analyzed by
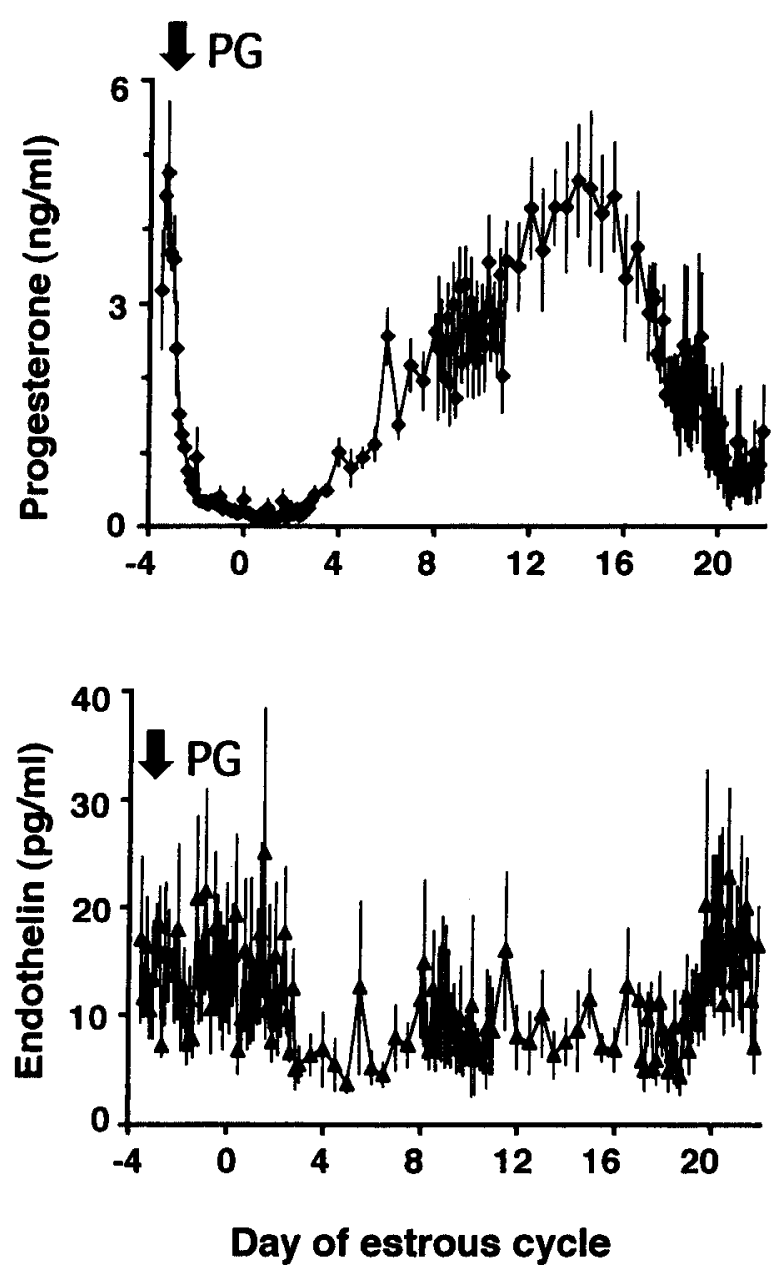

Fig. 1. Plasma concentrations of $\mathrm{P}_{4}$ and ET-1 during the estrous cycle after $\mathrm{PGF}_{2 \alpha}$ injection $(n=5$; Mean \pm SEM).

ANOVA, followed by the Tukey-Kramer test as a multiple comparison test. To compare the plasma hormone concentrations in the female calves among Days 1 to 7, Days 8 to 14, Days 15 to 21.5, and after $\mathrm{PGF}_{2 \alpha}$ injection (Days 22.5 to 26), data points during these periods were averaged, and the mean values were compared with each other. Data are presented as means \pm SEM. Means were analyzed by ANOVA, followed by the TukeyKramer test as a multiple comparison test.

\section{Results}

Changes in $\mathrm{P}_{4}$ and ET- 1 concentrations in the peripheral plasma during the estrous cycle after $\mathrm{PGF}_{2 \alpha}$ injection in cycling cows are shown in Fig. 1. 

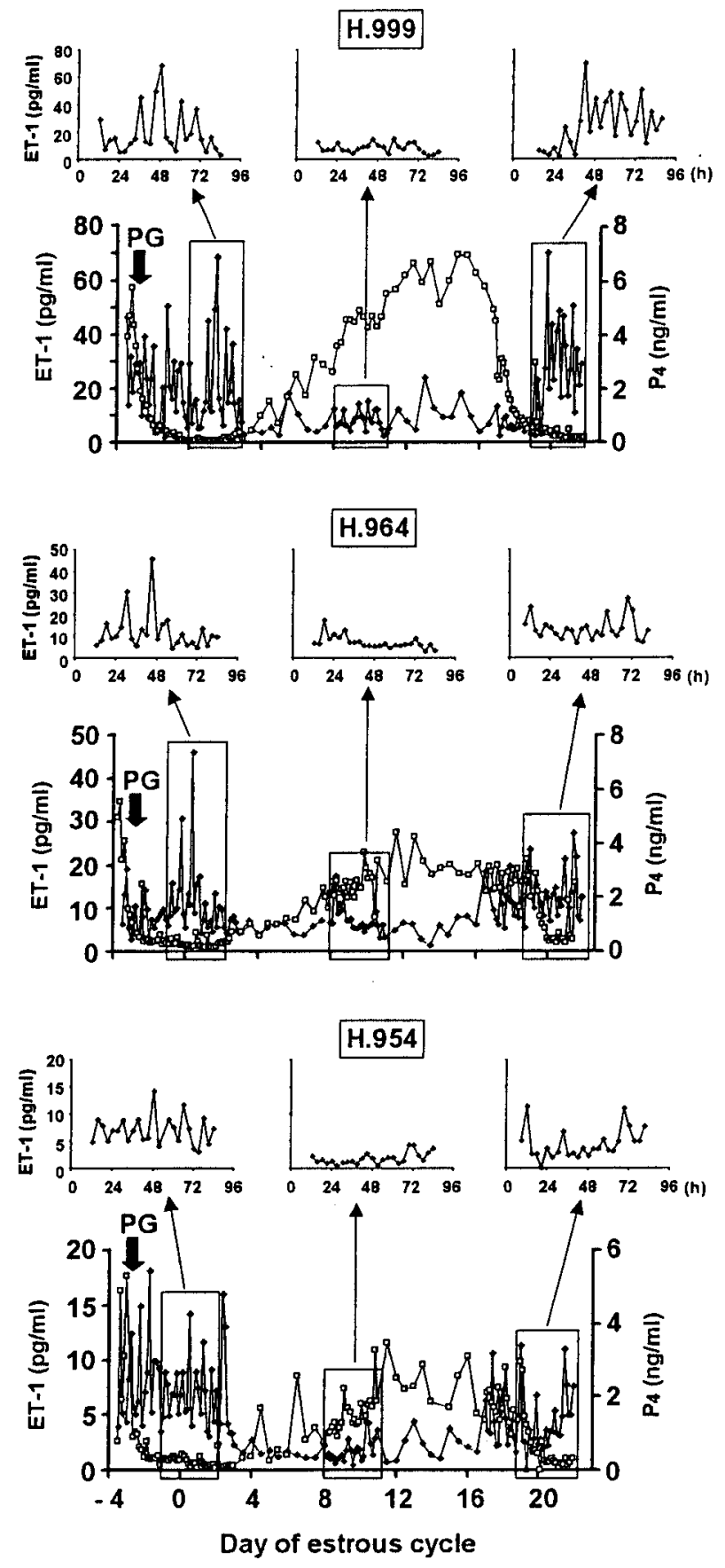

Fig. 2. Changes in ET-1 and $\mathrm{P}_{4}$ concentrations in the peripheral plasma of three cows during the estrous cycle after $\mathrm{PGF}_{2 \alpha}$ injection. The filled rhombus shows ET- 1 and the open square shows $\mathrm{P}_{4}$. The upper three panels of each cow show the ET-1 secretion pattern during three different periods (periestrous period after cloprostenol injection, mid luteal phase, and the second periestrous period) which are enclosed by a square in the lower panel. The active pulsatile release of ET- 1 is obvious during both periestrous periods, whereas no pulsatile pattern is observed during the mid luteal phase.
Three days after the $\mathrm{PGF}_{2 \alpha}$ injection, the five cycling cows showed estrus. This was designated as Day 0. Plasma $\mathrm{P}_{4}$ concentrations showed a typical pattern during the estrous cycle. Namely, they decreased immediately after $\mathrm{PGF}_{2 \alpha}$ injection, remained low until Day 2, gradually increased from Day 2 to Day 13, reached the highest level on Day 14 and decreased thereafter.

The peripheral plasma ET-1 concentrations in the cycling cows showed a pulsatile increase (Fig. 2). They reached the their highest level $(13.66 \mathrm{pg} / \mathrm{ml})$ around luteolysis and estrus, dropped to low levels during Days 2-12 (early to mid luteal phase) and Days 13-19 (late luteal phase) $(\mathrm{p}<0.05$, Table 1$)$ and then increased again on Days 20-22 ( $\mathrm{p}<0.05$, Table 1), when the next estrus appeared (Fig. 2).

Changes in $\mathrm{P}_{4}$ and ET- 1 concentrations in the peripheral plasma of the newborn, 120-day-old and 240 -day old female calves during 26 days are shown in Fig. 3. In all three groups of female calves, $\mathrm{P}_{4}$ concentrations remained at low levels $(0.1-0.2 \mathrm{ng} / \mathrm{ml})$. ET- 1 concentrations of these animals were lower than those of the cycling cows (Tables 1 and 2), and remained at low levels throughout the experimental period. Moreover, plasma ET-1 concentrations, unlike those in the cycling cows, did not change after a luteolytic $\mathrm{PGF}_{2 \alpha}$ injection.

\section{Discussion}

The results of the present study clearly demonstrated that peripheral plasma concentrations of ET-1 were highest around luteolysis and estrus in cycling cows. In addition, a luteolytic dose of $\mathrm{PGF}_{2 \alpha}$ analogue rapidly increased plasma ET-1 concentration in the cycling cows during the mid luteal phase. However, the same luteolytic dose of $\mathrm{PGF}_{2 \alpha}$ did not affect the plasma concentrations of ET-1 in the female calves lacking the ovarian cycle. Thus, this study confirmed our previous result on the changes in plasma ET-1 concentration during the estrous cycle [9], and showed for the first time that plasma ET-1 increased in a pulsatile manner.

On the basis of detailed observations of the relationship between plasma ET- 1 and $\mathrm{P}_{4}$ in each cow, the most active secretion of ET-1 appeared to correlate with estrus, rather than luteolysis. In this context, the bovine mature follicle has also been 

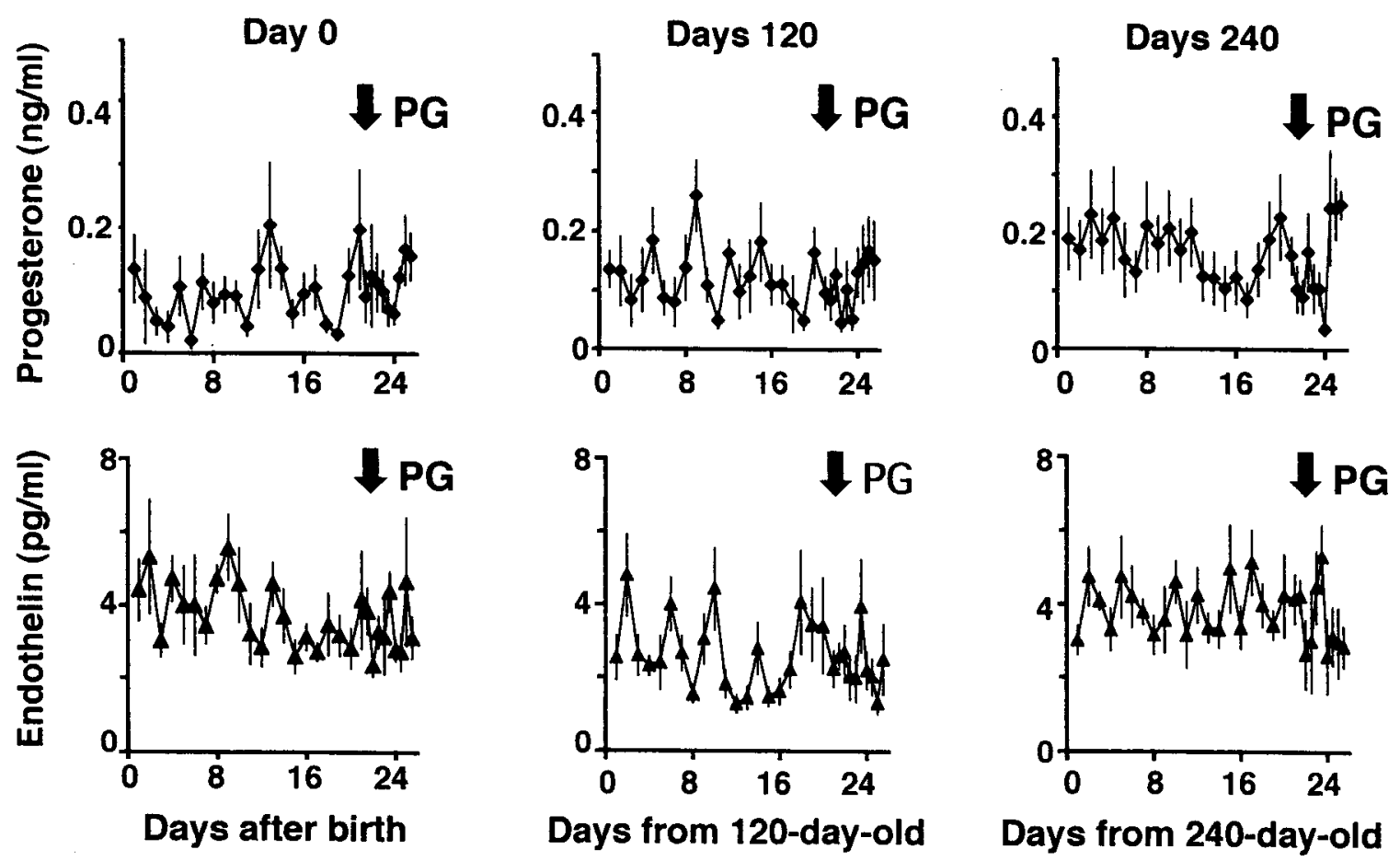

Fig. 3. Plasma concentrations of $\mathrm{P}_{4}$ and ET-1 during 26 days in 1-, 120-, and 240-day-old female calves (n=6; Mean \pm SEM)

Table 1. Plasma concentrations of progesterone and endothelin during estrous cycle in the cow $(\mathrm{n}=5$; Mean \pm SEM).

\begin{tabular}{lrccr}
\hline Cycling cows & Day -2 to 1 & Day 2 to 12 & Day 13 to 19 & Day 20 to 22 \\
\hline Progesterone $(\mathrm{ng} / \mathrm{ml})$ & $0.22 \pm 0.01^{\mathrm{a}}$ & $1.96 \pm 0.10^{\mathrm{c}}$ & $2.55 \pm 0.14^{\mathrm{d}}$ & $0.77 \pm 0.11^{\mathrm{b}}$ \\
Endothelin $(\mathrm{pg} / \mathrm{ml})$ & $13.66 \pm 0.97^{\mathrm{b}}$ & $8.98 \pm 0.58^{\mathrm{a}}$ & $9.00 \pm 0.60^{\mathrm{a}}$ & $16.46 \pm 1.39^{\mathrm{c}}$ \\
\hline
\end{tabular}

$\mathrm{a}, \mathrm{b}, \mathrm{c}, \mathrm{d}: \mathrm{p}<0.05$, among the time periods.

Table 2. Plasma concentrations of progesterone and endothelin during 26-day periods in female calves $(n=6$; Mean \pm SEM)*

\begin{tabular}{lcccc}
\hline Female calves & Day 1 to 7 & Day 8 to 14 & Day 15 to 21.5 & Day 22.5 to 26 \\
\hline $\begin{array}{l}\text { 1-day-old } \\
\quad \text { Progesterone }(\mathrm{ng} / \mathrm{ml})\end{array}$ & $0.08 \pm 0.02$ & $0.11 \pm 0.02$ & $0.10 \pm 0.02$ & $0.11 \pm 0.01$ \\
$\quad \begin{array}{l}\text { Endothelin }(\mathrm{pg} / \mathrm{ml}) \\
\text { 120-day-old }\end{array}$ & $4.13 \pm 0.36$ & $4.17 \pm 0.29$ & $3.72 \pm 0.27$ & $3.44 \pm 0.32$ \\
$\quad$ Progesterone $(\mathrm{ng} / \mathrm{ml})$ & $0.12 \pm 0.02$ & $0.13 \pm 0.02$ & $0.11 \pm 0.01$ & $0.11 \pm 0.02$ \\
$\quad$ Endothelin $(\mathrm{pg} / \mathrm{ml})$ & $3.04 \pm 0.28$ & $2.34 \pm 0.27$ & $2.64 \pm 0.28$ & $2.28 \pm 0.29$ \\
$\begin{array}{l}\text { 240-day-old } \\
\quad \text { Progesterone }(\mathrm{ng} / \mathrm{ml})\end{array}$ & $0.18 \pm 0.02$ & $0.18 \pm 0.02$ & $0.14 \pm 0.02$ & $0.17 \pm 0.02$ \\
$\quad$ Endothelin $(\mathrm{pg} / \mathrm{ml})$ & $3.98 \pm 0.26$ & $3.63 \pm 0.25$ & $4.01 \pm 0.27$ & $3.46 \pm 0.37$ \\
\hline
\end{tabular}

* There are no significant differences among the time periods at any age of calves.

shown to be the site of ET-1 secretion [14,15], in addition to $\mathrm{CL}[4,6,7,9]$. Interestingly, $\mathrm{LH}$ enhanced the ET-1 release from mature follicles in vitro [14], and the ET-1 concentration in the ovarian venous plasma increased immediately after the $\mathrm{LH}$ surge in the cow [16]. Thus, the active secretion of 
ET-1 during the periovulatory period may partly reflect increased ET-1 release from ovulatory follicles.

Recently, it has been shown that the intrauterine infusion of an $\mathrm{ET}_{\mathrm{A}}-\mathrm{R}$ antagonist on Days $16-18$ of the estrous cycle prolonged the functional lifespan of the $\mathrm{CL}$ and the $\mathrm{P}_{4}$ concentration declined more slowly than it did in normal luteolysis [17]. These findings suggest that ET- 1 of uterine origin takes part in the local control of uterine function via $\mathrm{ET}_{\mathrm{A}^{-}}$ $\mathrm{R}$ during luteolysis in the cow, and the production and binding of ET-1 in the endometrial cells have been demonstrated in ewes $[18,19]$. Considering the mass of the uterus and the $\mathrm{CL}$, the major part of the increase in plasma ET-1 during luteolysis might be the result of increased ET-1 production in the uterus rather than in the CL.

In support of this hypothesis, the plasma ET-1 levels observed in the calves $(2-6 \mathrm{pg} / \mathrm{ml})$ were well comparable with those in the cycling cows of the early to mid luteal phases $(5-10 \mathrm{pg} / \mathrm{ml})$, which were the lowest levels during the estrous cycle in the present study. These results imply that the increase of ET-1 secretion in the uterus after the onset of luteolysis may stimulate a local release of $\mathrm{PGF}_{2 \alpha}$ tow ard the CL. As $\mathrm{PGF}_{2 \alpha}$ is a clear stimulator of ET-1 from the CL $[4,6,7,9]$, the increased ET-1 release together with oxytocin from the regressing $C L$ might in turn accelerate the $\mathrm{PGF}_{2 \alpha}$ release from the uterus. Clearly, this hypothesis needs further investigation. Although the present study revealed a clear pulsatile secretion of ET-1 in the peripheral plasma during luteolysis and periovulatory period in the cow, the mechanism underlying the cause of such pulsatility and its physiological relevance are unclear.

At all ages of female calves, the peripheral plasma ET-1 concentrations showed only basal secretion without any clear pulses. In other words, the age before sexual maturation did not relate to the change in plasma ET-1 concentration, even after $\mathrm{PGF}_{2 \alpha}$ injection. The results suggest that the cyclic change in peripheral plasma ET-1 concentration depends on the active contraction of the uterus and the regression of functional CL.

In conclusion, the results of the present study gave the first detailed information that the plasma ET-1 concentrations increase in a pulsatile manner after the onsets of spontaneous luteolysis and $\mathrm{PGF}_{2 \alpha}$-induced luteolysis in cycling cows, but not in female calves. These results suggest that the cyclic changes in plasma ET-1 concentrations during the estrous cycle directly correlate with the cyclic changes in the function of the ovary and the uterus.

\section{Acknowledgements}

The authors thank Dr. K. Okuda, Okayama University, for $\mathrm{P}_{4}$ antiserum and Dr. D. Schams, Technical University of Munich, for ET-1 antiserum. This study was supported by Grants-inAid for Scientific Research (11660276 and 12556046) of the Japan Society for the Promotion of Science, and the grant from Morinaga Hohshikai Foundation.

\section{References}

1. Niswender GD, Reimer TJ, Diekman MA, Nett TM. Blood flow: a mediator of ovarian function. Biol Reprod 1976; 14: 64-81.

2. Ford SP, Chenault JR. Blood flow to the corpus luteum-bearing ovary and ipsilateral uterine horn of cows during the oestrous cycle and early pregnancy. J Reprod Fertil 1981; 62: 555-562.

3. Yanagisawa M, Kurihashi H, Kimura S, Tomobe $Y$, Kobayashi M, Mitsui Y, Yazaki Y, Goto K, Masaki T. A novel vasoconstrictor peptide produced by vascular endothelial cells. Nature 1988; 332: 411-415.

4. Girsh E, Wang W, Mamluk R, Arditi F, Friedman A, Milvae RA, Meidan R. Regulation of endothelin1 expression in the bovine corpus luteum: Elevation by prostaglandin $\mathrm{F}_{2 \alpha}$. Endocrinology 1996; 137: 51915196.

5. Mamluk R, Levy N, Rueda B, Davis JS, Meidan R. Characterization and regulation of type $A$ endothelin receptor gene expression in bovine luteal cell types. Endocrinology 1999; 140: 2110-2116.

6. Girsh E, Milvae RA, Wang W, Meidan R. Effect of endothelin-1 on bovine luteal cell function: role in prostaglandin $\mathrm{F}_{2 \alpha}$-induced antisteroidogenic action. Endocrinology 1996; 137: 1306-1312.

7. Miyamoto A, Kobayashi S, Arata S, Ohtani M, Fukui Y, Schams D. Prostaglandin $F_{2 \alpha}$ promotes the inhibitory action of endothelin-1 on the bovine luteal function in vitro. J Endocrinol 1997; 152: R7- 
R11.

8. Hayashi K, Miyamoto A. Angiotensin II interacts with prostaglandin $\mathrm{F}_{2 \alpha}$ and endothelin-1 as a local luteolytic factor in the bovine corpus luteum in vitro. Biol Reprod 1999; 60: 1104-1109.

9. Ohtani M, Kobayashi S, Miyamoto A, Hayashi K, Fukui Y. Real-time relationships between intraluteal and plasma concentrations of endothelin, oxytocin, and progesterone during prostaglandin $\mathrm{F}_{2 \alpha}$-induced luteolysis in the cow. Biol Reprod 1998; 58: 103-108.

10. Anggard EE. The endothelium the body's largest endocrine gland? J Endocrinol 1990; 127: 371-375.

11. Masaki T. Endothelins: homeostatic and compensatory actions in the circulatory and endocrine systems. Endocrine Reviews 1993; 14: 256268.

12. Stephenson K, Gandhi CR, Olson MS. Biological actions of endothelin. Vit and Hor 1994; 48: 157-198.

13. Miyamoto A, Okuda K, Schweigert FJ, Schams D. Effects of basic fibroblast growth factor, transforming growth factor-b and nerve growth factor on the secretory function of the bovine corpus luteum in vitro. J Endocrinol 1992; 135: 103-114.

14. Acosta TJ, Miyamoto A, Ozawa T, Wijayagunawardane MPB, Sato K. Local release of steroid hormones, prostaglandin $\mathrm{E}_{2}$, and endothelin-1 from bovine mature follicles in vitro: effects of luteinizing hormone, endothelin-1, and cytokines. Biol Reprod 1998; 437-443.

15. Acosta TJ, Berisha B, Ozawa T, Sato K, Schams D, Miyamoto A. Evidence for a local endothelinangiotensin-atrial natriuretic peptide system in bovine mature follicles in vitro: effects on steroid hormones and prostaglandin secretion. Biol Reprod 1999; 1419-1425.

16. Acosta TJ, Ozawa T, Kobayashi S, Hayashi K, Ohtani M, Kraetzl WD, Sato K, Schams D, Miyamoto A. Periovulatory changes in the local release of vasoactive peptides, prostaglandin $F_{2 \alpha}$, and steroid hormones from bovine mature follicles in vivo. Biol Reprod 2000; 1253-1261.

17. Keator CS, Milvae RA. Intrauterine infusions of an endothelin type A receptor antagonist delay bovine luteolysis. Biol Reprod 2000; 62(Suppl 1): abstract 272.

18. Riley SC, Butt AR, Doughton BW, Li S-X, Zheng SH, Findlay JK, Salamonsen LA. Endothelin in the ovine uterus during the oestrous cycle and early pregnancy. J Reprod Fertil 1994; 100: 451-459.

19. Riley SC, Findlay JK, Salamonsen LA. Endothelin1 and endothelin receptors are present in the sheep uterus and conceptus at implantation. J Endocrinol 1995; 147: 235-244. 